\title{
Effects of chia seed on chemical properties and quality characteristics of regular and low-fat crackers
}

\author{
Ayşe Neslihan DUNDAR ${ }^{1 *}$ (D), Emine AYDIN² (D), Elif YILDIZ³ (D), Ozen PARLAK ${ }^{3}$ (D)
}

\begin{abstract}
As a direct consequence of understanding the importance of the relationship between health and food, the interest in healthy recipes has increased. In the present study, wheat flour was used to replace chia seed (CS) in the cracker formulation (control) at levels of 10,20 , and $30 \%(\mathrm{w} / \mathrm{w})$ and fat content was reduced by 25,50 , and $75 \%$ for the production of low-fat crackers. The physicochemical, textural, sensorial properties of the crackers were investigated. It was determined that CS had high a dietary fiber $(38.7 \%)$, protein $(21.78 \%)$, and fat $(28.69 \%)$ content. The cracker sample containing $25 \%$ fat and $30 \%$ chia seed had the highest amounts of protein (14.49\%) and dietary fiber (16.70\%). CS could provide positive effects on health in terms of its high fiber content and low carbohydrate value. Six different fatty acids (FAs) were determined in the cracker samples. By reducing fat and increasing chia seed amount; oleic, linoleic, $\alpha$-linolenic increased compared to the control sample, whereas the palmitic acid amount decreased significantly. According to the sensorial evaluation, the crackers were acceptable. It was also determined that CS was a suitable supplementation for low-fat products.
\end{abstract}

Keywords: chia seed; cracker; low fat content; fatty acid; quality characteristic.

Practical Application: Evaluation of chia seed supplementation in low-fat bakery products.

\section{Introduction}

Healthy food composition has become more important than feeding people; As a result, the development of new products and healthy recipes that have a positive effect on health in terms of nutritional content has been the focus of scientific food studies. In recent years, chia (Salvia hispanica L.) seeds have been considered to be a popular food ingredient because of its health benefits. Chia seed (CS) is an annual herbaceous plant, typical of Mexico and Central America, and presents considerable amounts of dietary fiber, which helps to keep the water in its structure, to increase the feeling of satiety, to slow down digestion, and to lower insulin levels (Vuksan et al., 2007). Besides, it improves functions of the bowel, reduces serum cholesterol by inhibiting the absorption of bile acids, and protects against cardiovascular diseases (Borderías et al., 2005; Liu et al., 2015). CS is also a good source in terms of protein ranges from $15 \%$ to $23 \%$ and contains all essential amino acids in appropriate amounts (Yurt \& Gezer, 2018). Due to its protein and dietary fiber contents, chia is a good source of vitamins, minerals and phenolic compounds (Reyes-Caudillo et al., 2008) and higher polyunsaturated fatty acids that have beneficial effects on health-related disorders such as cardiovascular diseases, hypertension, obesity and diabetes (Hansel et al., 2007).

Crackers are commonly consumed as snacks and defined as thin bakery products and usually made of unsweetened and unleavened dough by soft wheat flour (Han et al., 2010). To obtain the desired quality attributes in the cracker, it is necessary to use low moisture and high shortening amount in the cracker dough (Lee \& Inglett, 2006 Fats prevent the formation of a gluten network in dough. The water or sugar solution, in the absence of fat, would interact with the flour protein to create cohesive and extensible gluten, but when fat is present, the fats surround the proteins and the starch granules, isolating them from the water, thereby breaking the continuity of protein and starch structure (Ghotra et al., 2002). For this reason, reducing fat in the cracker causes quality loss (Lee \& Inglett, 2006). Many researchers have used chia to improve the quality of fat content or to reduce the fat amount of bakery products. Borneo et al. (2010) prepared cakes adding 25, 50 and $75 \mathrm{~g}$ of chia gel $/ 100 \mathrm{~g}$ of eggs or oil and observed that an additional rate of $25 \%$ had no significant change in the color, taste, texture and general properties. Luna Pizarro et al. (2013) reported that the protein, fat and ash values of pound cake made with whole chia flour and vegetable oil increased significantly compared to the control cake. Fernandes \& Salas-Mellado (2017) examined chia mucilage incorporation on the technological quality of breads and pound cakes with a reduced fat content, and showed it to be an effective fat substitute, preserving quality attributes of food products. Nonetheless, the authors could not find any study reporting low-fat crackers supplemented with chia.

Crackers are greatly appreciated in bakery products consumed by individuals of all ages in the world. The objective of this study was to utilize CS in cracker production. Wheat flour was replaced with CS by $10,20,30 \%$, and fat content was decreased 25,50 , 
$75 \%$ in cracker production. The physicochemical, nutritional, and sensorial properties of the CS-substituted crackers were evaluated according to the control sample within the study.

\section{Materials and methods}

\subsection{Materials}

For the crackers, wheat flour was purchased from Toru Flour Milling Co. Ltd. (Bandirma/TURKEY). The other commercially available ingredients, including CS, salt, sodium bicarbonate, ammonium bicarbonate, shortening and yeast, were purchased from local stores in Bursa/TURKEY.

\subsection{Methods}

\section{Chemical analysis}

The moisture, ash, protein, fat, and dietary fiber of the CS were determined according to American Association of Cereal Chemists International (AACCI) Approved Methods of Analysis Methods No:44-15.02, 08-01.01, 46-10.01, 30-25.01, 32-21.01 respectively (American Association of Cereal Chemists International, 1999). Total carbohydrate and available carbohydrate values were evaluated according to Food and Agriculture Organization (2003).

\section{Cracker preparation}

The crackers were prepared by the single-stage fermentation method suggested by Lee et al. (2002). Some slight modifications were made in this method. Wheat flour was replaced with CS at levels of 10,20 , and $30 \%(\mathrm{w} / \mathrm{w})$ with four different fat ratios as $25,50,75,100 \%(\mathrm{w} / \mathrm{w})$ in the cracker formulations (Table 1 ). The dry ingredients were mixed homogeneously in a container for $30 \mathrm{sec}$. Shortening and some parts of the water were mixed in a separate container and then added into the mixture and kneaded (Kitchen-Aid model 5SS, St. Joseph, MI, USA) for $120 \mathrm{sec}$. The rest of the water was used for the activation of the yeast. The cracker dough was kneaded for $4 \mathrm{~min}$. Afterward, the dough was proofed at appropriate relative humidity (90\%) for $2 \mathrm{~h}\left(35^{\circ} \mathrm{C}\right)$. The thickness dough was reduced to $1.5 \mathrm{~mm}$ by Lamination Machine (Commercial Food Preparing Machine, TMM Inc., Turkey). The spread dough was cut into a cracker size of $5 \times 5 \mathrm{~cm}$ by a specially designed cutter-docker. Then, the crackers were baked in a convection oven (Inoksan FKE 006, TR) for $7 \mathrm{~min}$ at $180^{\circ} \mathrm{C}$. After baking, the crackers were cooled at room temperature $(\sim 30 \mathrm{~min})$. The sensorial and physical evaluation was performed after $24 \mathrm{~h}$. Subsequently, the cracker samples were grounded and kept in hermetical plastic bags, inside a dark cabinet at room temperature.

\section{Physical evaluation of crackers}

The dimensions of the crackers were evaluated in terms of width, length, and thickness according to the AACCI Method No:10.54 (American Association of Cereal Chemists International, 1995). The color (top and bottom surface) of ten randomly selected cracker samples was determined by the Minolta Spectrophotometer (CM-3600d; Osaka, Japan) in terms of $L^{*}, a^{*}, b^{*}$ values. The texture of the cracker samples was evaluated in terms of the hardness by a texture analyzer (TA-XT PLUS, Stable)

Table 1. Formulation of crackers incorporated with chia seed.

\begin{tabular}{|c|c|c|c|c|c|c|c|c|}
\hline $\begin{array}{l}\text { Fat } \\
\text { Ratio }\end{array}$ & Sample & Wheat Flour (g) & CS (g) & Shortening (g) & Water (g) & $\mathrm{NaHCO}_{3}(\mathrm{~g})$ & $\mathrm{NH}_{4} \mathrm{HCO}_{3}(\mathrm{~g})$ & Salt (g) \\
\hline \multirow[t]{3}{*}{$100 \%$} & 1 & 100.00 & 0.00 & 13.00 & 40.00 & 0.50 & 2.00 & 1.60 \\
\hline & 3 & 80.00 & 20.00 & 13.00 & 40.00 & 0.50 & 2.00 & 1.60 \\
\hline & 4 & 70.00 & 30.00 & 13.00 & 40.00 & 0.50 & 2.00 & 1.60 \\
\hline \multirow{3}{*}{$75 \%$} & 6 & 90.00 & 10.00 & 9.75 & 40.00 & 0.50 & 2.00 & 1.60 \\
\hline & 7 & 80.00 & 20.00 & 9.75 & 40.00 & 0.50 & 2.00 & 1.60 \\
\hline & 8 & 70.00 & 30.00 & 9.75 & 40.00 & 0.50 & 2.00 & 1.60 \\
\hline \multirow[t]{2}{*}{$50 \%$} & 9 & 100.00 & 0.00 & 6.50 & 40.00 & 0.50 & 2.00 & 1.60 \\
\hline & 10 & 90.00 & 10.00 & 6.50 & 40.00 & 0.50 & 2.00 & 1.60 \\
\hline \multirow{3}{*}{$25 \%$} & 14 & 90.00 & 10.00 & 3.25 & 40.00 & 0.50 & 2.00 & 1.60 \\
\hline & 15 & 80.00 & 20.00 & 3.25 & 40.00 & 0.50 & 2.00 & 1.60 \\
\hline & 16 & 70.00 & 30.00 & 3.25 & 40.00 & 0.50 & 2.00 & 1.60 \\
\hline
\end{tabular}

CS: Chia Seed, $\mathrm{NaHCO}_{3}$ : Sodium bicarbonate, $\mathrm{NH}_{4} \mathrm{HCO}_{3}$ : Ammonium bicarbonate. 


\section{Determination of fatty acids}

For the fatty acid (FA) analysis, the oil extraction process was firstly performed. For this purpose, hexane/isopropanol $(2 \mathrm{v} / \mathrm{v})$ was used (Hara \& Radin, 1978). The oil extracts were centrifuged at $10.000 \mathrm{xg}$ for $5 \mathrm{~min}$ and then filtered. The solution was separated by rotary evaporator at $40{ }^{\circ} \mathrm{C}$. For the determination of the quantities of FAs; methylation was first carried out according to the AOAC Method (No: 969.33; Association of Official Analytical Chemist, 2000). $100 \mathrm{mg}$ of oil sample, $3 \mathrm{~mL}$ of hexane and $100 \mu \mathrm{L}$ potassium hydroxide $(2 \mathrm{~N}$ in methanol) were taken into centrifuge tubes, vortexed for a while and centrifuged at $5000 \mathrm{rpm}$ for $5 \mathrm{~min}$ (Association of Official Analytical Chemist, 1990). One mL of supernatant was analyzed by Gas Chromatography. Gas chromatography (Agilent, GC model 6890N) was used for the analysis of FAs, equipped with a capillary column $(100 \mathrm{~m} \times 0.25 \mathrm{~mm}$ ID, $0.2 \mu \mathrm{m}$ Supelco HP 88) and a flame ionization detector (FID). The injection volume was set at $1 \mu \mathrm{L}$ while the injection temperature was set at $250{ }^{\circ} \mathrm{C}$. A temperature gradient was established for the $\mathrm{GC}$ oven temperature. It was kept at $130{ }^{\circ} \mathrm{C}$ for $1 \mathrm{~min}$ and then increased to $6.5^{\circ} \mathrm{C} / \mathrm{min}$ at $170{ }^{\circ} \mathrm{C}$. In the next step, the increase in temperature for $12 \mathrm{~min}$, the increase in temperature of $40^{\circ} \mathrm{C} / \mathrm{min}$ to $230{ }^{\circ} \mathrm{C}$ and in this temperature was kept for $5 \mathrm{~min}$. The total analysis time was recorded as 40.89 minutes. The split detector temperature was $280^{\circ} \mathrm{C}$, while the detector $\mathrm{H}_{2}$ flow rate was $40 \mathrm{~mL} / \mathrm{min}$, the dry air flow rate was $450 \mathrm{~mL} / \mathrm{min}$ and the column $\mathrm{H}_{2}$ flow rate was $1.3 \mathrm{~mL} / \mathrm{min}$ (Tulukcu et al., 2012).

\section{Sensory evaluation}

25 untrained panelists, who were between 20-35 years of age, screened the sensory characteristics of the crackers. Cracker properties such as color, surface smoothness, firmness of internal structure, internal color, external and internal color difference, crispiness, dry-grained structure, dissolubility in the mouth, stickiness to tooth and flavor were evaluated. A 9-point hedonic scale was used. The final evaluation was calculated by averaging the scores given by all the panelists.

\section{Statistical analysis}

SPSS (24.0) software was used to perform the statistical analyses. The data were analyzed for variance using the one-way analysis of variance (ANOVA). When significant differences were observed ( $p \leq 0.05)$, the least significant difference (LSD) test was performed to determine the differences among the means.

\section{Results and discussion}

\subsection{Physicochemical properties of chia seed}

The physicochemical composition of the CS is presented in Table 2. According to the results, the CS had a low moisture content $(6.13 \%)$. Fernandes \& Salas-Mellado (2017) and Ferrari-Felisberto et al. (2015) were determined the moisture content of CS respectively as 5.74 and $6.52 \%$. These results were found to be in accordance with our study. The ash content of the CS used in the cracker production was determined as $4.31 \%$, while it was determined as $4.30 \%$ (Coelho \& Salas-Mellado 2014).

CS has richer protein content than commonly used cereals such as wheat, corn, rice, amaranth (Bushway et al., 1981), and consists of essential amino acids and non-essential nitrogen for the human organism (Silva et al., 2017). The protein content (21.78\%) of the CS was similar to that of previous studies (Table 2). Fernandes \& Salas-Mellado (2017) and Ferrari-Felisberto et al. (2015) determined it as 19.55 and $24.36 \%$, respectively.

In this study, the fat content of the CS was determined as $28.69 \%$ (Table 2). According to Muñoz et al. (2013), CS generally includes $30-35 \%$ fat amount. Location, climatic conditions, harvesting time affect fat amount and the fatty acid content. CS is rich in polyunsaturated fatty acids (PUFAs) and monounsaturated fatty acids (MUFA) (Orona-Tamayo et al., 2017; de Falco \& Lanzotti, 2018). Particularly, CS has the highest a-linolenic acid (C18:3) content of all plants (Muñoz et al., 2013). This fatty acid has also been associated with various health benefits. In this study, $\alpha$-linolenic acid was found to be $60.27 \%$ (Table 3 ). Our results were similar to those studies of Sargi et al. (2013), Coelho \& Salas-Mellado, (2014) and a-linolenic acid content of CS determined. respectively as 54.40 and $62.02 \%$. In addition, linoleic (17.95\%) and oleic (5.28\%) acids, which are unsaturated, are the most common fatty acids after a-linolenic acid (60.27\%). Similar results for linoleic acid (C18:2) were obtained by previous studies conducted by Coelho \& Salas-Mellado (2014), Sargi et al. (2013) and Ayerza \& Coates, (2011); they were determined the linoleic acid content of CS respectively as $17.36,17.47$ and $17.65 \%$. The oleic acid content found in this study was also in compliance with that of the studies carried out by Sargi et al. (2013; 5.91\%) and Ayerza \& Coates (2011; 6.84\%).

Stearic (2.76\%) and palmitic acid (6.26\%) are saturated fatty acids in CS used in low-fat cracker production. Stearic acid is found in the literature as $2.49 \%$ (Sargi et al., 2013), $2.98 \%$ (Bodoira et al., 2017), 3.80\% (Ixtaina et al., 2012), while palmitic is found as 5.85\% (Sargi et al., 2013), 7.20\% (Ixtaina et al., 2012) and $7.46 \%$ (Bodoira et al., 2017).

Table 2. Physicochemical properties of chia seed.

\begin{tabular}{|c|c|c|c|c|c|c|c|c|c|}
\hline \multirow[b]{2}{*}{ Sample } & \multirow[b]{2}{*}{ Moisture (\%) } & \multirow[b]{2}{*}{ Ash (\%) } & \multirow[b]{2}{*}{ Protein (\%) } & \multirow[b]{2}{*}{ Fat (\%) } & \multicolumn{2}{|c|}{ Total Carbohydrate } & \multicolumn{3}{|c|}{ Color values } \\
\hline & & & & & $\begin{array}{c}\text { Dietary Fiber } \\
(\%)\end{array}$ & $\begin{array}{c}\text { Available } \\
\text { Carbohydrate }(\%)^{* *}\end{array}$ & $\mathrm{~L}^{*}$ & $a^{*}$ & \\
\hline
\end{tabular}

${ }^{* *}$ Available Carbohydrate calculated according to Food and Agriculture Organization (2003). All data are expressed as mean \pm standard deviations ( $\mathrm{n}=3$ ). 
The total carbohydrate value was determined as $39.09 \%$ and only $0.39 \%$ of this amount consisted of available carbohydrates. CS is a good source of total dietary fibre (TDF) $(38.70 \%)$ (Table 2). Gómez-Favela et al. (2017) revealed a similar result (42.52\%). TDF amount is an important component for daily diet for beneficial properties on cholesterolemia, glycemic and insulinemic responses, intestinal function and metabolism (Reyes-Caudillo et al., 2008). CS includes 34-40\% dietary fiber that could meet $100 \%$ of the daily recommendation for the adult population (Bushway et al., 1981; Reyes-Caudillo et al., 2008). According to epidemiological studies, CS is also beneficial for the prevention of cardiovascular diseases, diabetes and metabolic disorders (Anderson et al., 1994; Ayerza \& Coates, 2001; Marlett et al., 2002; Anderson et al., 2009). CS had high carbohydrate fraction (39.09\%) and similar results were determined by United States Department of Agriculture Research Service (2017) (42.10\%), and the high carbohydrate content were associated with the high amount of dietary fiber (Muñoz et al., 2012). The color measurements of the CS is presented in (Table 2) as $36.69,3.02,13.85$; for $L^{*}, a^{*}, b^{*}$ values.

\subsection{Physicochemical properties of cracker samples}

\section{Chemical properties of cracker samples}

Moisture content in food is a criterion of quality. Moreover, it is one of the desirable sensory characteristics in bakery products and generally related to mild products (Dadkhah Hashemiravan et al., 2012). In this study, the replacement of wheat flour by CS into the cracker formulations decreased the moisture content slightly and changed it between $7.17 \%$ and $7.75 \%$ (Table 4 ). The changes in the fat ratio of the crackers did not change the moisture content significantly. A similar effect was observed by Mesías et al. (2016).

Related with the chemical composition of the CS, by the higher substitution levels; ash, protein, fat, and TDF contents were increased in the cracker samples (Table 4). Contrary to the general myth, protein from plant sources can meet human protein needs. The high protein content can be used to strengthen diets as a step towards a more sustainable diet (Vrancheva et al., 2019). In terms of the protein content of the crackers, by the CS addition, there was a slight increase in the crackers; however, when they

Table 3. Fatty acid composition of chia seeds.

\begin{tabular}{ccccccc}
\hline Sample & $\begin{array}{c}\text { Myristic Acid } \\
(\mathrm{C} 14: 0)\end{array}$ & $\begin{array}{c}\text { Palmitic Acid } \\
(\mathrm{C} 16: 0)\end{array}$ & $\begin{array}{c}\text { Stearic Acid } \\
(\mathrm{C} 18: 0)\end{array}$ & $\begin{array}{c}\text { Oleic Acid } \\
(\mathrm{C} 18: 1)\end{array}$ & $\begin{array}{c}\text { Linoleic Acid } \\
(\mathrm{C} 18: 2)\end{array}$ & $\begin{array}{c}\alpha \text {-Linolenic Acid } \\
(\mathrm{C} 18: 3)\end{array}$ \\
\hline Chia Seed & $0.03 \pm 0.01$ & $6.26 \pm 0.12$ & $2.76 \pm 0.05$ & $5.28 \pm 0.27$ & $17.95 \pm 0.59$ & $60.27 \pm 1.54$ \\
\hline
\end{tabular}

Table 4. Chemical properties of crackers supplemented with chia seed.

\begin{tabular}{|c|c|c|c|c|c|c|c|c|}
\hline \multirow[b]{2}{*}{ Samples } & \multirow[b]{2}{*}{$\begin{array}{c}\text { Fat Addition } \\
\text { Ratio (\%) }\end{array}$} & \multirow[b]{2}{*}{$\begin{array}{c}\text { Chia } \\
\text { Addition } \\
\text { Level (\%) }\end{array}$} & \multirow[b]{2}{*}{ Moisture (\%) } & \multirow[b]{2}{*}{ Total Ash (\%) } & \multirow[b]{2}{*}{$\begin{array}{c}\text { Total Protein } \\
(\%)\end{array}$} & \multirow[b]{2}{*}{ Total Fat (\%) } & \multicolumn{2}{|c|}{ Total Carbohydrate } \\
\hline & & & & & & & $\begin{array}{c}\text { Dietary Fiber } \\
(\%)\end{array}$ & $\begin{array}{c}\text { Available } \\
\text { Carbohydrate } \\
(\%)^{*}\end{array}$ \\
\hline \multirow[t]{2}{*}{ C 1} & 100 & 0 & $7.62 \pm 0.23$ & $0.71 \pm 0.01^{\mathrm{cD}}$ & $11.15 \pm 0.53^{\mathrm{bE}}$ & $11.27 \pm 0.03^{\mathrm{dD}}$ & $3.19 \pm 0.02^{\mathrm{dH}}$ & $66.06 \pm 0.04^{\mathrm{aD}}$ \\
\hline & & 10 & $7.50 \pm 0.34$ & $0.73 \pm 0.01^{\mathrm{cCD}}$ & $12.79 \pm 0.12^{\mathrm{aCD}}$ & $12.33 \pm 0.12^{\mathrm{cC}}$ & $7.29 \pm 0.03^{\mathrm{cF}}$ & $59.36 \pm 0.34^{\mathrm{bH}}$ \\
\hline \multirow[t]{4}{*}{ C 2} & 75 & 0 & $7.66 \pm 0.09^{\mathrm{a}}$ & $0.74 \pm 0.00^{c \mathrm{C}}$ & $11.53 \pm 0.54^{\mathrm{bE}}$ & $9.08 \pm 0.34^{\mathrm{dFG}}$ & $3.38 \pm 0.04^{\mathrm{dGH}}$ & $67.61 \pm 0.03^{\mathrm{aC}}$ \\
\hline & & 10 & $7.51 \pm 0.03^{\mathrm{ab}}$ & $0.77 \pm 0.01^{\mathrm{cC}}$ & $13.06 \pm 0.09^{\mathrm{aC}}$ & $9.85 \pm 0.65^{\mathrm{cE}}$ & $7.58 \pm 0.12^{\mathrm{cEF}}$ & $61.23 \pm 0.34^{\mathrm{bG}}$ \\
\hline & & 20 & $7.35 \pm 0.12^{\mathrm{b}}$ & $0.96 \pm 0.01^{\mathrm{bB}}$ & $13.28 \pm 0.17^{\mathrm{aBC}}$ & $11.23 \pm 0.12^{\mathrm{bD}}$ & $12.00 \pm 0.95^{\mathrm{bCD}}$ & $55.18 \pm 0.33^{\mathrm{cJ}}$ \\
\hline & & 30 & $7.28 \pm 0.43^{b}$ & $1.22 \pm 0.02^{\mathrm{aA}}$ & $13.70 \pm 0.09^{\mathrm{aB}}$ & $13.42 \pm 0.16^{\mathrm{aB}}$ & $15.80 \pm 0.12^{\mathrm{aB}}$ & $47.58 \pm 0.76^{\mathrm{dN}}$ \\
\hline C 3 & & 30 & $7.32 \pm 0.09^{\mathrm{b}}$ & $1.23 \pm 0.03^{\mathrm{aA}}$ & $14.08 \pm 0.03^{\mathrm{aA}}$ & $11.53 \pm 0.04^{\mathrm{aD}}$ & $16.00 \pm 0.02^{\mathrm{aB}}$ & $48.84 \pm 0.44^{\mathrm{dM}}$ \\
\hline \multirow[t]{4}{*}{ C 4} & 25 & 0 & $7.75 \pm 0.71$ & $0.71 \pm 0.01^{\mathrm{cD}}$ & $12.30 \pm 0.12^{\mathrm{dD}}$ & $4.36 \pm 0.12^{\mathrm{dK}}$ & $3.95 \pm 0.27^{\mathrm{dG}}$ & $70.93 \pm 0.12^{\mathrm{aA}}$ \\
\hline & & 10 & $7.64 \pm 0.02$ & $0.78 \pm 0.02^{\mathrm{cC}}$ & $13.43 \pm 0.24^{\mathrm{cBC}}$ & $5.07 \pm 0.15^{\mathrm{cJ}}$ & $8.13 \pm 0.30^{\mathrm{cE}}$ & $64.95 \pm 0.19^{\mathrm{bE}}$ \\
\hline & & 20 & $7.59 \pm 0.04$ & $0.99 \pm 0.03^{\mathrm{bB}}$ & $13.91 \pm 0.12^{\mathrm{bAB}}$ & $7.31 \pm 0.16^{\mathrm{bH}}$ & $12.71 \pm 0.65^{\mathrm{bC}}$ & $59.49 \pm 0.03^{\mathrm{cH}}$ \\
\hline & & 30 & $7.37 \pm 0.06$ & $1.24 \pm 0.01^{\mathrm{aA}}$ & $14.49 \pm 0.18^{\mathrm{aA}}$ & $9.13 \pm 0.18^{\mathrm{aEF}}$ & $16.70 \pm 0.34^{\mathrm{aA}}$ & $51.07 \pm 0.56^{\mathrm{dL}}$ \\
\hline
\end{tabular}

*Available Carbohydrate calculated according to Food and Agriculture Organization (2003). All data are expressed as mean \pm standard deviations ( $\mathrm{n}=3$ ). Mean values showed with different lower letters in the same column for each CS addition levels are significantly different $(\mathrm{p} \leq 0.05)$. Mean values showed with different capital letters in the same column for each cracker samples are significantly different $(\mathrm{p} \leq 0.05)$. 
compared to the control sample, a significant increase was observed (Table 4). As expected, the fat ratio did not affect the protein contents. The highest protein content was determined in the $30 \%$ CS added and $75 \%$ fat decreased sample as $14.49 \%$, whereas the lowest one was the control (11.15\%). When the protein values were compared with those of previous studies; it can be seen that Mesías et al. (2016), and Brandão et al. (2019) observed the same levels of protein content in CS-added cookies.

The fat content of the crackers increased significantly and correspondingly with the CS amount. Sung et al. (2020) investigated that the addition of CS increased the protein value of gluten-free rice layer cake. While the protein value of the control sample was $13.83 \%$, the value of the cake with $30 \%$ chia was $17.37 \%$. Similar results and tendencies were revealed in the studies of Mesías et al. (2016) and Brandão et al. (2019).

Dietary fiber consumption is recommended $25-30 \mathrm{~g} /$ per day by many health institutions around the world (Dashti et al., 2003). Ho et al. (2013) observed that individuals consuming bread fortified with CS had lower postprandial glycaemia in comparison to individuals who consumed bread free from that additive. Those authors suggested that the hypoglycemic effect of chia seeds resulted from their high content dietary fiber. In the cracker samples, the TDF values were changed between 3.19\% (control) and $16.70 \%$ (30\% CS added $75 \%$ fat decreased sample). By the increase of CS ratio, the TDF content increased significantly. Despite the decrease of the fat ratio in the formulation of the crackers, TDF amount was increased in small quantities. Brandão et al. (2019) determined the TDF content as $12.71 \%$ for $20 \%$ CS-added cookies, while we determined it as $11.58 \%$ in the $20 \%$ CS-added crackers.
The increase in the addition of fat and/or CS ratio caused a decrease in the available carbohydrate values significantly. For this reason, the crackers obtained in this study can be safely consumed by individuals who are on a low nutrition diet. On the other hand, by the CS increase, the available carbohydrate value of the crackers increased compared with the control sample (Table 4).

\section{Physical properties of cracker samples}

The color measurements of the CS crackers are shown in Table 5. Due to the CS color values, as CS amount increased and fat amount decreased, together and separately, $L^{*}$ and $b^{*}$ values of cracker samples were decreased and $a^{\star}$ values were increased in top and bottom surfaces. Bilgiçli et al. (2007) reported that cooking parameters, such as temperature and time, were effective on bakery products in terms of the Maillard reaction with other ingredients. Brandão et al. (2019) prepared cookies with chia seeds and flour. As fat content increased in CS-cracker samples, $L^{*}$ and $b^{\star}$ values decreased, while $a^{*}$ value increased slightly.

The baking characteristic of the crackers are presented in Table 6 . Although the crackers were cut in $5 \times 5$ size and baked, some dimensional differences occurred in the crackers. They were determined to be $0.36-0.48 \mathrm{~cm}$ of thickness, $4.58-4.62 \mathrm{~cm}$ of width and $4.67-4.76 \mathrm{~cm}$ of length. The thickness of the $30 \%$ CS-added crackers were decreased significantly in all the fat ratio groups compared to no CS-added cracker samples. Other dimension measurements did not show statistically significant changes.

Textural properties are important quality determinants for crackers (Yilmaz \& Karaman, 2017). According to

Table 5. Color properties of crackers supplemented with chia seed.

\begin{tabular}{|c|c|c|c|c|c|c|c|c|}
\hline \multirow{2}{*}{ Samples } & \multirow{2}{*}{$\begin{array}{c}\text { Fat Addition } \\
\text { Ratio (\%) }\end{array}$} & \multirow{2}{*}{$\begin{array}{l}\text { Chia Addition } \\
\text { Level (\%) }\end{array}$} & \multicolumn{3}{|c|}{ Top Surface Color } & \multicolumn{3}{|c|}{ Bottom Surface Color } \\
\hline & & & $L^{*}$ & $\mathrm{a}^{*}$ & $\mathrm{~b}^{*}$ & $L^{*}$ & $\mathrm{a}^{*}$ & $b^{*}$ \\
\hline \multirow[t]{3}{*}{ C 1} & 100 & 0 & $64.72 \pm 0.22^{\mathrm{aA}}$ & $2.11 \pm 0.54^{\mathrm{dM}}$ & $26.35 \pm 0.44^{\mathrm{aA}}$ & $63.97 \pm 0.54^{\mathrm{aA}}$ & $1.55 \pm 0.53^{\mathrm{dK}}$ & $27.25 \pm 0.94^{\mathrm{aA}}$ \\
\hline & & 20 & $57.73 \pm 0.52^{\mathrm{cD}}$ & $6.50 \pm 0.76^{\mathrm{bG}}$ & $22.23 \pm 0.49^{\mathrm{cE}}$ & $59.64 \pm 0.50^{\mathrm{cF}}$ & $6.42 \pm 0.57^{\mathrm{bE}}$ & $22.19 \pm 0.73^{\mathrm{cF}}$ \\
\hline & & 30 & $56.69 \pm 0.12^{\mathrm{dE}}$ & $8.96 \pm 0.11^{\mathrm{aC}}$ & $19.39 \pm 0.83^{\mathrm{dH}}$ & $56.43 \pm 0.43^{\mathrm{d} J}$ & $8.29 \pm 0.95^{\mathrm{aC}}$ & $20.32 \pm 0.55^{\mathrm{dH}}$ \\
\hline \multirow{3}{*}{ C 2} & & 10 & $59.42 \pm 0.19^{\mathrm{bC}}$ & $5.22 \pm 0.77^{\mathrm{cI}}$ & $24.12 \pm 0.60^{\mathrm{bD}}$ & $60.58 \pm 0.12^{\mathrm{bE}}$ & $4.57 \pm 0.60^{\mathrm{cH}}$ & $24.90 \pm 0.54^{\mathrm{bDE}}$ \\
\hline & & 20 & $57.10 \pm 0.31^{\mathrm{cDE}}$ & $6.80 \pm 0.88^{\mathrm{bFG}}$ & $22.17 \pm 0.92^{\mathrm{cEF}}$ & $58.26 \pm 0.76^{\mathrm{cG}}$ & $6.83 \pm 0.12^{\mathrm{bDE}}$ & $22.08 \pm 0.77^{\mathrm{cF}}$ \\
\hline & & 30 & $55.78 \pm 0.543^{\mathrm{dF}}$ & $9.60 \pm 0.91^{\mathrm{aB}}$ & $19.43 \pm 0.65^{\mathrm{dH}}$ & $54.79 \pm 0.69^{\mathrm{dK}}$ & $9.51 \pm 0.64^{\mathrm{aB}}$ & $20.28 \pm 0.22^{\mathrm{dHI}}$ \\
\hline C 3 & 50 & 0 & $64.19 \pm 0.87^{\mathrm{aA}}$ & $2.95 \pm 0.76^{\mathrm{dKL}}$ & $26.24 \pm 0.58^{\mathrm{aA}}$ & $63.52 \pm 0.43^{\mathrm{aBC}}$ & $2.96 \pm 0.77^{\mathrm{di}}$ & $26.61 \pm 0.97^{\mathrm{aAB}}$ \\
\hline \multirow[t]{4}{*}{ C 4} & 25 & 0 & $60.97 \pm 0.34^{\mathrm{aB}}$ & $3.03 \pm 0.17^{\mathrm{dK}}$ & $25.63 \pm 0.77^{\mathrm{aB}}$ & $63.27 \pm 0.59^{\mathrm{aC}}$ & $3.11 \pm 0.53^{\mathrm{di}}$ & $25.34 \pm 0.84^{\mathrm{aCD}}$ \\
\hline & & 10 & $57.18 \pm 0.87^{\mathrm{bDE}}$ & $5.91 \pm 0.81^{\mathrm{cH}}$ & $24.16 \pm 0.54^{\mathrm{bCD}}$ & $57.08 \pm 0.12^{\mathrm{bi}}$ & $5.13 \pm 0.95^{\mathrm{cFG}}$ & $24.21 \pm 0.53^{\mathrm{bE}}$ \\
\hline & & 20 & $56.41 \pm 0.98^{\mathrm{bEF}}$ & $7.74 \pm 0.23^{\mathrm{bD}}$ & $21.40 \pm 0.10^{\mathrm{cG}}$ & $57.08 \pm 0.31^{\mathrm{bi}}$ & $7.99 \pm 0.43^{\mathrm{bC}}$ & $21.37 \pm 0.78^{\mathrm{cG}}$ \\
\hline & & 30 & $54.02 \pm 0.66^{\mathrm{cH}}$ & $10.43 \pm 0.83^{\mathrm{aA}}$ & $19.05 \pm 0.65^{\mathrm{dH}}$ & $53.62 \pm 0.34^{\mathrm{cM}}$ & $10.10 \pm 0.24^{\mathrm{aA}}$ & $19.58 \pm 0.21^{\mathrm{di}}$ \\
\hline
\end{tabular}

All data are expressed as mean \pm standard deviations $(n=3)$. Mean values showed with different lower letters in the same column for each CS addition levels are significantly different $(\mathrm{p} \leq 0.05)$. Mean values showed with different capital letters in the same column for each cracker samples are significantly different $(\mathrm{p} \leq 0.05)$. 
Table 6. Texture and dimension properties of crackers supplemented with CS.

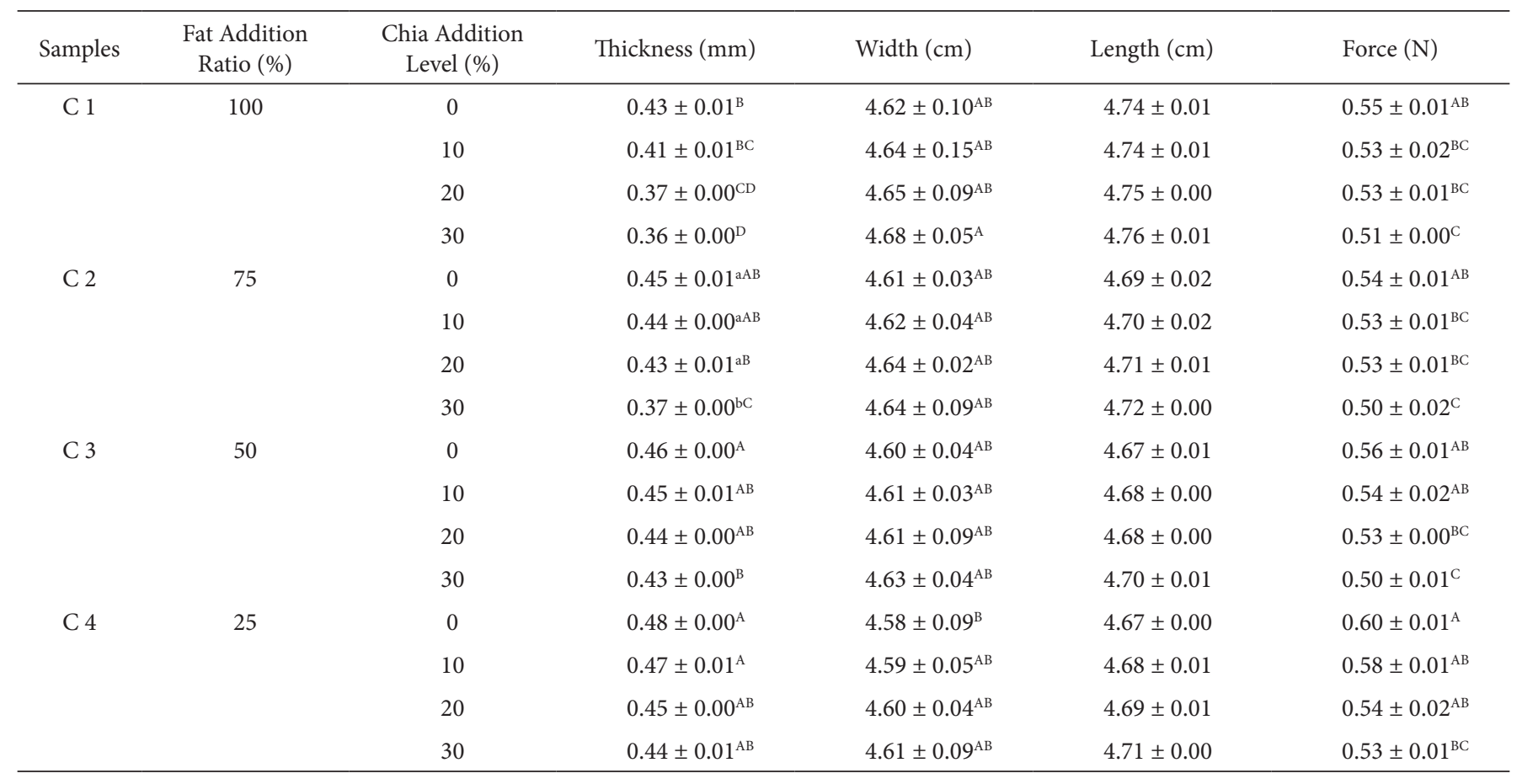

All data are expressed as mean \pm standard deviations $(n=3)$. Mean values showed with different lower letters in the same column for each CS addition levels are significantly different $(\mathrm{p} \leq 0.05)$. Mean values showed with different capital letters in the same column for each cracker samples are significantly different $(p \leq 0.05)$.

Howard et al. (2009), consumers expect a crispy, fragile, and crunchy crackers. The breaking force of the crackers changed between $0.50-0.60 \mathrm{~N}$ (Table 6). With the increasing percentage of CS, the hardness of the crackers decreased in all the samples. Nevertheless, regardless of the fat ratio, it was determined that the crackers containing $25 \%$ fat were harder than the other crackers.

\section{Fatty acid content of cracker samples}

In accordance with the CS content, as the CS ratio increased; oleic, linoleic, and a-linolenic acid (unsaturated fatty acids) increased significantly, while palmitic, stearic acid (saturated fatty acids) decreased compared to the control sample. In terms of the fat reduction, only oleic acid content was increased; linoleic, a-linolenic, myristic, palmitic and stearic acids were decreased.

In the fatty acid analysis; myristic, palmitic, stearic, oleic, linoleic and $\alpha$-linolenic acids were detected in the cracker samples as $0.17-0.23 \%, 7.48-8.60 \%, 0.88-0.97 \%, 6.97-9.27 \% 1.61-7.28 \%$, 0.01-7.21\%, respectively (Table 7). PUFAs (linoleic and a-linolenic acids) and MUFA (oleic acid) are associated with various health benefits. These fatty acids' value increased significantly. The highest increase in fatty acid with the addition of chia was determined in a-linolenic acid. The 75\% fat-decreased control sample had $0.01 \%$ a-linolenic acid, while the 30\% CS-supplemented cracker was contained $7.21 \%$ a-linolenic acid, considering having the same fat content. Similarly, in the study of Sung et al. (2020), a-linolenic acid was significantly increased from $0.28 \%$ (the control group) to $10.78 \%$ with $30 \%$ chia seed flour replacement in rice flour the cakes.
It is known that the increased ratio oleic/stearic acids are desirable for the prevention of numerous diseases (Simopoulos, 2008). In this study, the calculated ratio C18:1/C18:0 varied from 7.18 to 10.19 . As the chia supplementation ratio increased or the fat supplementation ratio decreased, this ratio increased. The evaluation of the ratio $\mathrm{C} 18: 1 / \mathrm{C} 18: 0$ showed that the healthiest cracker was the 30\% CS-added and 75\% fat-decreased sample. Therefore, it can easily be said that the produced crackers were healthier snacks than commercial ones and the controls.

\section{Sensorial evaluation of cracker samples}

The sensory properties of the crackers were examined under 4 main headings: surface appearance, cut view properties, sense of taste, and overall acceptability. The surface properties were determined considering color and surface smoothness. The color values changed between 5.8 and 8.6. The surface smoothness of the crackers decreased as the amount of added fats decreased. There were no statistical differences between all the samples about their surface properties.

To determine the cut view properties of the crackers, the panelists evaluated the firmness of the internal structure, internal color, external and internal color differences. These values were $5.8-8.2,5.2-8.0$ and 5.6-8.2, respectively. The changes in the chia or fat supplementation ratio did not cause statistical differences between the samples.

The panelists examined the crispiness, dry-grained structure, dissolubility in the mouth, stickiness to tooth and flavor properties of the crackers, which helped the determination of the sense of taste property. When the supplementation fat 
Table 7. Fatty acid composition of crackers supplemented with chia seed.

\begin{tabular}{|c|c|c|c|c|c|c|c|c|}
\hline Sample & $\begin{array}{c}\text { Fat Addition } \\
\text { Ratio (\%) }\end{array}$ & $\begin{array}{l}\text { Chia Addition } \\
\text { Level (\%) }\end{array}$ & $\begin{array}{l}\text { Myristic Acid } \\
\text { (C14:0) }\end{array}$ & $\begin{array}{l}\text { Palmitic Acid } \\
\quad(\mathrm{C} 16: 0)\end{array}$ & $\begin{array}{l}\text { Stearic Acid } \\
\quad(\mathrm{C} 18: 0)\end{array}$ & $\begin{array}{l}\text { Oleic Acid } \\
\text { (C18:1) }\end{array}$ & $\begin{array}{l}\text { Linoleic Acid } \\
\quad(\mathrm{C} 18: 2)\end{array}$ & $\begin{array}{c}\text { a-Linolenic } \\
\text { Acid (C18:3) }\end{array}$ \\
\hline \multirow[t]{3}{*}{$\mathrm{C} 1$} & 100 & 0 & $0.23 \pm 0.08^{\mathrm{A}}$ & $8.60 \pm 0.01^{\mathrm{A}}$ & $0.97 \pm 0.01^{\mathrm{A}}$ & $6.97 \pm 0.05^{\mathrm{cJ}}$ & $2.00 \pm 0.01^{\mathrm{dG}}$ & $0.05 \pm 0.00^{\mathrm{dH}}$ \\
\hline & & 20 & $0.22 \pm 0.02^{\mathrm{AB}}$ & $8.27 \pm 0.09^{\mathrm{ABCD}}$ & $0.95 \pm 0.01^{\mathrm{AB}}$ & $7.73 \pm 0.07^{\mathrm{aHi}}$ & $4.06 \pm 0.01^{\mathrm{bDE}}$ & $3.29 \pm 0.00^{\mathrm{bE}}$ \\
\hline & & 30 & $0.21 \pm 0.03^{\mathrm{AB}}$ & $8.07 \pm 0.02^{\mathrm{CDEF}}$ & $0.96 \pm 0.00^{\mathrm{AB}}$ & $7.94 \pm 0.03^{\mathrm{aGH}}$ & $5.95 \pm 0.03^{\mathrm{aB}}$ & $5.52 \pm 0.01^{\mathrm{aB}}$ \\
\hline \multirow{3}{*}{$\mathrm{C} 2$} & & 10 & $0.22 \pm 0.02^{\mathrm{AB}}$ & $8.24 \pm 0.08^{\mathrm{ABCDE}}$ & $0.93 \pm 0.01^{\mathrm{AB}}$ & $8.41 \pm 0.05^{\mathrm{abDEF}}$ & $3.16 \pm 0.01^{\mathrm{cF}}$ & $1.87 \pm 0.00^{\mathrm{cF}}$ \\
\hline & & 20 & $0.21 \pm 0.01^{\mathrm{AB}}$ & $8.17 \pm 0.59^{\mathrm{BCDEF}}$ & $0.94 \pm 0.01^{\mathrm{AB}}$ & $8.72 \pm 0.02^{\mathrm{aBCD}}$ & $4.96 \pm 0.01^{\mathrm{bC}}$ & $3.35 \pm 0.01^{\mathrm{bDE}}$ \\
\hline & & 30 & $0.21 \pm 0.00^{\mathrm{AB}}$ & $7.99 \pm 0.12^{\mathrm{DEFG}}$ & $0.92 \pm 0.00^{\mathrm{AB}}$ & $8.85 \pm 0.05^{\mathrm{aABCD}}$ & $6.03 \pm 0.01^{\mathrm{aB}}$ & $5.73 \pm 0.01^{\mathrm{aB}}$ \\
\hline \multirow[t]{2}{*}{$\mathrm{C} 3$} & 50 & 0 & $0.21 \pm 0.02^{\mathrm{AB}}$ & $8.24 \pm 0.18^{\mathrm{aABCDE}}$ & $0.93 \pm 0.00^{\mathrm{AB}}$ & $8.28 \pm 0.01^{\mathrm{bEFG}}$ & $1.70 \pm 0.01^{\mathrm{dG}}$ & $0.03 \pm 0.00^{\mathrm{dH}}$ \\
\hline & & 10 & $0.20 \pm 0.01^{\mathrm{AB}}$ & $8.11 \pm 0.43^{\mathrm{abCDEF}}$ & $0.91 \pm 0.01^{\mathrm{AB}}$ & $8.60 \pm 0.05^{\mathrm{abCDE}}$ & $3.50 \pm 0.01^{\mathrm{cEF}}$ & $1.96 \pm 0.00^{\mathrm{cF}}$ \\
\hline \multirow[t]{4}{*}{$\mathrm{C} 4$} & 25 & 0 & $0.21 \pm 0.02^{\mathrm{AB}}$ & $7.88 \pm 0.47^{\mathrm{EFG}}$ & $0.93 \pm 0.01^{\mathrm{AB}}$ & $8.65 \pm 0.09^{\mathrm{bCDE}}$ & $1.61 \pm 0.01^{\mathrm{dG}}$ & $0.01 \pm 0.00^{\mathrm{dH}}$ \\
\hline & & 10 & $0.20 \pm 0.02^{\mathrm{AB}}$ & $7.80 \pm 0.12^{\mathrm{FG}}$ & $0.92 \pm 0.00^{\mathrm{AB}}$ & $8.87 \pm 0.03^{\mathrm{abABC}}$ & $3.95 \pm 0.01^{\mathrm{cE}}$ & $1.76 \pm 0.00^{\mathrm{cFG}}$ \\
\hline & & 20 & $0.19 \pm 0.02^{\mathrm{AB}}$ & $7.63 \pm 0.43^{\mathrm{GH}}$ & $0.92 \pm 0.01^{\mathrm{AB}}$ & $9.12 \pm 0.04^{\mathrm{aAB}}$ & $4.98 \pm 0.01^{\mathrm{bC}}$ & $4.01 \pm 0.01^{\mathrm{bC}}$ \\
\hline & & 30 & $0.17 \pm 0.02^{\mathrm{B}}$ & $7.40 \pm 0.74^{\mathrm{H}}$ & $0.91 \pm 0.01^{\mathrm{AB}}$ & $9.27 \pm 0.05^{\mathrm{aA}}$ & $7.01 \pm 0.01^{\mathrm{aA}}$ & $7.21 \pm 0.01^{\mathrm{aA}}$ \\
\hline
\end{tabular}

Values are given as g per100 g sample. All data are expressed as mean \pm standard deviations $(n=3)$. Mean values showed with different lower letters in the same column for each CS addition levels are significantly different $(\mathrm{p} \leq 0.05)$. Mean values showed with different capital letters in the same column for each cracker samples are significantly different $(\mathrm{p} \leq 0.05)$.

ratio increased or the chia ratio decreased, the properties of crispness and dissolubility in the mouth values increased and the values of dry-grained structure, stickiness to tooth and flavor decreased. These differences were not statistically significant. According to the sense of taste, the most liked was the $50 \%$ fat and $30 \%$ chia-added cracker, while the least liked was the $25 \%$ fat control sample.

The overall acceptability values of crackers ranged between 5.46-7.10 ("neither like nor dislike" to "like moderately"). There was no statistical difference between the samples. According to the sensory analysis results, all the crackers were acceptable for the panelists.

\section{Conclusion}

As a consequence of the increasing interest in health foods, studies focused on producing healthy recipes and revealing the characteristics of these products. Chia (Salvia hispanica L.) seed, known for its fatty acid, protein, total dietary fiber content, was utilized for the healthy snack formulation. In this context, wheat flour was replaced with CS by $10,20,30 \%$ in order to decrease the fat content at the rate of $25,50,75 \%$ in the cracker production.

The moisture, ash, protein, fat and total dietary fiber and available carbohydrate content of the CS used in the production were determined as $6.13,4.31,21.78,38.7,28.69$ and $0.39 \%$, respectively. The fatty acid content was also determined in terms of myristic, palmitic, stearic, oleic, linoleic and $\alpha$-linolenic acids as 0.03, 6.26, 2.76, 5.28, 17.95 and $60.27 \%$, respectively.
As a result of the increase of the CS amount in the crackers; the ash, protein, fat, dietary fiber contents increased while the moisture and available carbohydrate contents were decreased. With the increase of the fat amount; the moisture, ash, protein, dietary fiber contents increased; whereas the fat and available carbohydrate contents decreased. The CS addition enriched the cracker samples in terms of oleic, linoleic, and $\alpha$-linolenic acids (unsaturated fatty acids).

The new cracker formulation was found acceptable by the panelists. The $L^{*}$ and $b^{*}$ values decreased while the $a^{*}$ value increased in the final cracker samples according to the control sample. The breaking force of the crackers increased by the CS addition and decreased by the fat reduction.

As a result, CS is a suitable ingredient to be used in bakery products. With the addition of CS, crackers, having a high nutritional value, reduced fat content, and acceptable sensory and textural properties, can be produced. Among the produced crackers, $75 \%$ fat reduction and 30\% CS addition had the highest nutritional value.

\section{Acknowledgements}

This work was supported by the Scientific Research Council of Bursa Technical University (Project No: 171N06).

\section{References}

American Association of Cereal Chemists International - AACCI. (1995). Approved methods of American Association of Cereal Chemists International. St. Paul: AACCI. 
American Association of Cereal Chemists International - AACCI. (1999). Approved method of the American Association of Cereal Chemists. St. Paul: AACCI.

Anderson, J. W., Baird, P., Davis, R. H., Jr., Ferreri, S., Knudtson, M., Koraym, A., Waters, V., \& Williams, C. L. (2009). Health benefits of dietary fiber. Nutrition Reviews, 67(4), 188-205. http://dx.doi. org/10.1111/j.1753-4887.2009.00189.x. PMid:19335713.

Anderson, J. W., Smith, B. M., \& Gustafson, N. J. (1994). Health benefits and practical aspects of high-fiber diets. The American Journal of Clinical Nutrition, 59(5, Suppl.), 1242-1247. http://dx.doi.org/10.1093/ ajcn/59.5.1242S. PMid:8172129.

Association of Official Analytical Chemist - AOAC. (1990). Official methods of analysis (15th ed.). Washington: AOAC.

Association of Official Analytical Chemist - AOAC. (2000). Official methods of analysis: method 969.33: fatty acids in oils and fats: preparation of methyl esters boron trifluoride method. Washington: AOAC.

Ayerza, R., \& Coates, W. (2001). Chia seeds: new source of omega-3 fatty acids, natural antioxidants, and dietetic fiber. Tucson: Southwest Center for Natural Products Research \& Commercialization, Office of Arid Lands Studies.

Ayerza, R., \& Coates, W. (2011). Protein content, oil content and fatty acid profiles as potential criteria to determine the origin of commercially grown chia (Salvia hispanica L.). Industrial Crops and Products, 34(2), 1366-1371. http://dx.doi.org/10.1016/j.indcrop.2010.12.007.

Bilgiçli, N., İbanog `lu, Ş., \& Herken, E. N. (2007). Effect of dietary fiber addition on the selected nutritional properties of cookies. Journal of Food Engineering, 78(1), 86-89. http://dx.doi.org/10.1016/j. jfoodeng.2005.09.009.

Bodoira, R. M., Penci, M. C., Ribotta, P. D., \& Martínez, M. L. (2017). Chia (Salvia hispanica L.) oil stability: Study of the effect of natural antioxidants. Lebensmittel-Wissenschaft + Technologie, 75, 107-113. http://dx.doi.org/10.1016/j.lwt.2016.08.031.

Borderías, A. J., Sánchez-Alonso, I., \& Pérez-Mateos, M. (2005). New applications of fibres in foods: addition to fishery products. Trends in Food Science \& Technology, 16(10), 458-465. http://dx.doi. org/10.1016/j.tifs.2005.03.011.

Borneo, R., Aguirre, A., \& Leon, A. E. (2010). Chia (Salvia hispanica L.) gel can be used as egg or oil replacer in cake formulations. Journal of the American Dietetic Association, 110(6), 946-949. http://dx.doi. org/10.1016/j.jada.2010.03.011. PMid:20497788.

Brandão, N. A., Lima Dutra, M. B., Gaspardi, A. L. A., \& Campos, M. R. S. (2019). Chia (Salvia hispanica L.) cookies: physicochemical/ microbiological attributes, nutrimental value and sensory analysis. Journal of Food Measurement and Characterization, 13(2), 1100-1110. http://dx.doi.org/10.1007/s11694-018-00025-z.

Bushway, A. A., Belyea, P. R., \& Bushway, R. J. (1981). Chia seed as a source of oil, polysaccharide, and protein. Journal of Food Science, 46(5), 1349-1350. http://dx.doi.org/10.1111/j.1365-2621.1981.tb04171.x.

Coelho, M. S., \& Salas-Mellado, M. M. (2014). Chemical characterization of chia (Salvia hispanica L.) for use in food products. Journal of Food and Nutrition Research, 2(5), 263-269. http://dx.doi.org/10.12691/jfnr-2-5-9.

Dadkhah Hashemiravan, A., Hashemiravan, M., \& Seyedain-Ardebili, M. (2012). Effect of shortening replacement with nutrim oat bran on chemical and physical properties of shortened cakes. Annals of Biological Research, 3, 2682-2687.

Dashti, B., Al-Awadi, F., Khalafawi, M. S., Sawaya, W., \& Al Amiri, H. (2003). Soluble and insoluble dietary fibre in thirty-two Kuwaiti dishes. Food Chemistry, 83(4), 557-561. http://dx.doi.org/10.1016/ S0308-8146(03)00153-5. de Falco, B., \& Lanzotti, V. (2018). NMR spectroscopy and mass spectrometry in metabolomics analysis of Salvia. Phytochemistry Reviews, 17(5), 951-972. http://dx.doi.org/10.1007/s11101018-9550-8.

Fernandes, S. S., \& Salas-Mellado, M. L. (2017). Addition of chia seed mucilage for reduction of fat content in bread and cakes. Food Chemistry, 227, 237-244. http://dx.doi.org/10.1016/j.foodchem.2017.01.075. PMid:28274428.

Ferrari-Felisberto, M. H., Wahanik, A. L., Gomes-Ruffi, C. R., Clerici, M. T. P. S., Chang, Y. K., \& Steel, C. J. (2015). Use of chia (Salvia hispanica L.) mucilage gel to reduce fat in pound cakes. Lebensmittel-Wissenschaft + Technologie, 63(2), 1049-1055. http:// dx.doi.org/10.1016/j.lwt.2015.03.114.

Food and Agriculture Organization - FAO. (2003). Food energy: methods of analysis and conversion factors: report of a technical workshop (FAO Food and Nutrition, No. 77). Rome: FAO.

Ghotra, B. S., Dyal, S. D., \& Narine, S. S. (2002). Lipid shortenings: a review. Food Research International, 35(10), 1015-1048. http:// dx.doi.org/10.1016/S0963-9969(02)00163-1.

Gómez-Favela, M. A., Gutiérrez-Dorado, R., Cuevas-Rodríguez, E. O., Canizalez-Román, V. A., \& León-Sicairos, C. (2017). Improvement of Chia Seeds with Antioxidant Activity, GABA, Essential Amino Acids, and Dietary Fiber by Controlled Germination Bioprocess. Plant Foods for Human Nutrition (Dordrecht, Netherlands), 72(4), 345352. http://dx.doi.org/10.1007/s11130-017-0631-4. PMid:28900797.

Han, J., Janz, J. A. M., \& Gerlat, M. (2010). Development of glutenfree cracker snacks using pulse flours and fractions. Food Research International, 43(2), 627-633. http://dx.doi.org/10.1016/j. foodres.2009.07.015.

Hansel, B., Nicolle, C., Lalanne, F., Tondu, F., Lassel, T., Donazzolo, Y., Ferrières, J., Krempf, M., Schlienger, J.-L., Verges, B., Chapman, M. J., \& Bruckert, E. (2007). Effect of low-fat, fermented milk enriched with plant sterols on serum lipid profile and oxidative stress in moderate hypercholesterolemia. The American Journal of Clinical Nutrition, 86(3), 790-796. http://dx.doi.org/10.1093/ajcn/86.3.790. PMid:17823447.

Hara, A., \& Radin, N. S. (1978). Lipid extraction of tissues with a lowtoxicity solvent. Analytical Biochemistry, 90(1), 420-426. http:// dx.doi.org/10.1016/0003-2697(78)90046-5. PMid:727482.

Ho, H., Lee, A. S., Jovanovski, E., Jenkins, A. L., Desouza, R., \& Vuksan, V. (2013). Effect of whole and ground Salba seeds (Salvia hispanica L.) on postprandial glycemia in healthy volunteers: a randomized controlled, dose-response trial. European Journal of Clinical Nutrition, 67(7), 786-788. http://dx.doi.org/10.1038/ejcn.2013.103. PMid:23778782.

Howard, B. M., McWatters, K. H., Saalia, F., \& Hashim, I. (2009). Formulation and evaluation of snack crackers made with peanut flour. Cereal Foods World, 54, 166-171.

Ixtaina, V. Y., Nolasco, S. M., \& Tomás, M. C. (2012). Oxidative stability of chia (Salvia hispanica L.) seed oil: effect of antioxidants and storage conditions. Journal of the American Oil Chemists' Society, 89(6), 1077-1090. http://dx.doi.org/10.1007/s11746-011-1990-x.

Lee, L., Ng, P. K. W., \& Steffe, J. F. (2002). A modified procedure (One Stage Fermentation) for evaulating flour cracker-making potential. Food Engineering Progress, 6, 201-207.

Lee, S., \& Inglett, G. E. (2006). Rheological and physical evaluation of jet-cooked oat bran in low calorie cookie. International Journal of Food Science \& Technology, 41(5), 553-559. http://dx.doi. org/10.1111/j.1365-2621.2005.01105.x. 
Liu, L., Wang, S., \& Liu, J. (2015). Fiber consumption and all-cause, cardiovascular, and cancer mortalities: A systematic review and meta-analysis of cohort studies. Molecular Nutrition \& Food Research, 59(1), 139-146. http://dx.doi.org/10.1002/mnfr.201400449. PMid:25382817.

Luna Pizarro, P., Almeida, E. L., Samman, N. C., \& Chang, Y. K. (2013). Evaluation of whole chia (Salvia hispanica L.) flour and hydrogenated vegetable fat in pound cake. Lebensmittel-Wissenschaft + Technologie, 54(1), 73-79. http://dx.doi.org/10.1016/j.lwt.2013.04.017.

Marlett, J. A., McBurney, M. I., \& Slavin, J. L. (2002). Position of the American Dietetic Association: Health implications of dietary fiber. Journal of the American Dietetic Association, 102(7), 993-1000. http://dx.doi.org/10.1016/S0002-8223(02)90228-2. PMid:12146567.

Mesías, M., Holgado, F., Márquez-Ruiz, G., \& Morales, F. J. (2016). Risk/ benefit considerations of a new formulation of wheat-based biscuit supplemented with different amounts of chia flour. LebensmittelWissenschaft + Technologie, 73, 528-535. http://dx.doi.org/10.1016/j. lwt.2016.06.056.

Muñoz, L. A., Cobos, A., Diaz, O., \& Aguilera, J. M. (2012). Chia seeds: microstructure, mucilage extraction and hydration. Journal of Food Engineering, 108(1), 216-224. http://dx.doi.org/10.1016/j. jfoodeng.2011.06.037.

Muñoz, L. A., Cobos, A., Diaz, O., \& Aguilera, J. M. (2013). Chia seed (Salvia hispanica): an ancient grain and a new functional food. Food Reviews International, 29(4), 394-408. http://dx.doi.org/10.1080/8 7559129.2013 .818014$.

Orona-Tamayo, D., Valverde, M. E., \& Paredes-Lopez, O. (2017). Chia-The New Golden Seed for the 21st Century: Nutraceutical Properties and Technological Uses. In S. Nadathur (Ed.), Sustainable protein sources (pp. 265-281). Academic Press.

Reyes-Caudillo, E., Tecante, A., \& Valdivia-López, M. A. (2008). Dietary fibre content and antioxidant activity of phenolic compounds present in Mexican chia (Salvia hispanica L.) seeds. Food Chemistry, 107(2), 656-663. http://dx.doi.org/10.1016/j.foodchem.2007.08.062.

Sargi, S. C., Silva, B. C., Santos, H. M. C., Montanher, P. F., Boeing, S., Santos Júnior, O. O., Souza, N. E., \& Visentainer, J. V. (2013). Antioxidant capacity and chemical composition in seeds rich in omega-3: chia, flax, and perilla. Food Science and Technology, 33(3), 541-548. http://dx.doi.org/10.1590/S0101-20612013005000057.
Silva, B. P., Anunciação, P. C., Matyelka, J. C. D. S., Della Lucia, C. M., Martino, H. S. D., \& Pinheiro-Sant'Ana, H. M. (2017). Chemical composition of Brazilian chia seeds grown in different places. Food Chemistry, 221, 1709-1716. http://dx.doi.org/10.1016/j. foodchem.2016.10.115. PMid:27979151.

Simopoulos, A. P. (2008). The importance of the omega-6/omega-3 Fatty Acid ratio in cardiovascular disease and other chronic diseases. Experimental Biology and Medicine, 233(6), 674-688. http://dx.doi. org/10.3181/0711-MR-311. PMid:18408140.

Sung, W. C., Chiu, E. T., Sun, A., \& Hsiao, H. I. (2020). Incorporation of chia seed flour into gluten-free rice layer cake: effects on nutritional quality and physicochemical properties. Journal of Food Science, 85(3), 545-555. http://dx.doi.org/10.1111/1750-3841.14841. PMid:31999371.

Tulukcu, E., Yalcin, H., Ozturk, O., \& Sagdic, O. (2012). Changes in the fatty acid compositions and bioactivities of clary sage seeds depending on harvest year. Industrial Crops and Products, 39, 69-72. http://dx.doi.org/10.1016/j.indcrop.2012.02.012.

United States Department of Agriculture Research Service - USDA. (2017). USDA Food Composition Database. Retrieved from https:// ndb.nal.usda.gov/ndb/foods/show/115 42? $\mathrm{manu}=\& \mathrm{fgcd}=\& \mathrm{ds}=$

Vrancheva, R., Krystev, L., Popova, A., \& Mihaylova, D. (2019). Proximate nutritional composition and heat-induced changes of starch in selected grains and seeds. Emirates Journal of Food and Agriculture, 31(9), 718-724. http://dx.doi.org/10.9755/ejfa.2019.v31.i9.2011.

Vuksan, V., Whitham, D., Sievenpiper, J. L., Jenkins, A. L., Rogovik, A. L., Bazinet, R. P., Vidgen, E., \& Hanna, A. (2007). Supplementation of conventional therapy with the novel grain Salba (Salvia hispanica L.) improves major and emerging cardiovascular risk factors in type 2 diabetes: results of a randomized controlled trial. Diabetes Care, 30(11), 2804-2810. http://dx.doi.org/10.2337/dc07-1144. PMid:17686832.

Yilmaz, E., \& Karaman, E. (2017). Functional crackers: incorporation of the dietary fibers extracted from citrus seeds. Journal of Food Science and Technology, 54(10), 3208-3217. http://dx.doi.org/10.1007/ s13197-017-2763-9. PMid:28974806.

Yurt, M., \& Gezer, C. (2018). Functional characteristics of chia seed (Salvia Hispanica) and its effects on health. Food, 43(3), 446-460. 